\title{
The Effects of an Educational Intervention on COVID-19 Knowledge, Attitudes, and Behaviors in People with Migratory Background: A Before-after Study
}

\author{
Zekeriya Aktürk, Klaus Linde, Alexander Hapfelmeier, Raphael Kunisch, and Antonius Schneider
}

\section{ABSTRACT}

Background: This study investigated the feasibility to conduct an educational webinar for improving COVID-19-related knowledge, attitudes, and behaviors in Munich.

Methods: A before-after experiment was conducted in Turkish-speaking family physician offices. Turkish-speaking participants $(n=245)$ of a crosssectional study evaluating COVID-19 knowledge, attitudes, and behaviors were invited to an educational webinar. COVID-19 vaccination intention and knowledge ( 25 true/false items) were the primary outcomes. Also, attitudes and behaviors to COVID-19 vaccination were asked using Likert scales (min. 1, max. 5).

Results: Knowledge (22.8 \pm 1.5 vs. $23.1 \pm 1.5)$ and behavior $(4.1 \pm 0.4$ vs. $4.2 \pm 0.3)$ scores did not change after the intervention, nor changed the intention to be vaccinated $(p>0.05)$. However, there was a significant increase in the attitude scores from mean $3.9 \pm 0.5$ to $4.2 \pm 0.5(p=0.009)$. The webinar received high scores (mean $4.7 \pm 0.2)$.

Conclusion: We suggest educational interventions involving key persons from the Turkish-speaking community as peer trainers to change the negative attitudes towards vaccination.

Keywords: SARS-CoV, Immigrants, Inequalities, Vaccination Refusal, Vulnerable Populations.
Submitted : July 06, 2021

Published : July 31, 2021

ISSN: $2593-8339$

DOI: $10.24018 /$ ejmed.2021.3.4.974

\section{Zekeriya Aktürk*}

Institute of General Practice and Health Services Research, School of Medicine, Technical University of Munich, Germany.

(e-mail: zekeriya.aktuerk@mri.tum.de) Klaus Linde

Institute of General Practice and Health Services Research, School of Medicine, Technical University of Munich, Germany.

(e-mail: klaus.linde@ ${ }^{@}$ tum.de)

Alexander Hapfelmeier

Institute of General Practice and Health Services Research-Institute of Medical Informatics, Statistics and Epidemiology, School of Medicine, Technical University of Munich, Germany.

(e-mail:

Alexander.Hapfelmeier@mri.tum.de)

Raphael Kunisch

Institute of General Practice, School of Medicine, Universitätsklinikum Erlangen, Germany

(e-mail: raphael.kunisch@ ${ }^{@}$ uk-erlangen.de) Antonius Schneider

Institute of General Practice and Health Services Research, School of Medicine, Technical University of Munich, Germany.

(e-mail: antonius.schneider@ tum.de)

*Corresponding Author

\section{INTRODUCTION}

People coming from Turkey constitute the highest proportion of citizens with foreign origin in Germany [1]. More than three million people with a migration background in Germany have their roots in Turkey [2]. There are around 40 thousand people of Turkish origin in Munich [3]. On the other side, there are growing concerns about the vaccine rejection proportions in Turkey [4], and there is growing influence of Turkey on people in Germany with Turkish roots [5].

In a cross-sectional study conducted among Turkish- and German-speaking patients in Munich, we found that in contrast to $57.7 \%$ of the participants with a migratory background, $33.5 \%$ of the non-immigrant Germans were hesitating to be vaccinated against the COVID-19. The most common reasons for vaccine refusal were safety or mistrust in vaccines, the perception that vaccines were not sufficiently studied, and conspiracy theories. A multivariable analysis showed that non-migratory background $(\mathrm{OR}=3.1)$ and attitude scores $(\mathrm{OR}=2.9)$ were significant factors affecting the decision to be vaccinated [6].

It has been shown that citizens with Turkish backgrounds experience difficulties with the integration to the German community [7]. We hypothesized that an educational intervention using distant learning facilities could contribute 
to the knowledge, attitudes, and behaviors of Turkishspeaking citizens in Germany.

\section{OBJECTIVES}

This study aimed to investigate the feasibility to conduct an educational Zoom event for improving COVID-19-related knowledge levels, attitudes, and behaviors in Turkish speaking people in Munich.

\section{METHODS}

\section{A. Study Design and Setting}

A single-arm before-after experimental study was conducted. The study was approved by the ethics committee of the Medical Faculty of the Technical University of Munich (Date: $20^{\text {th }}$ of January 2021, Number: 37/21 S-EB). Using a one-page information leaflet, all participants were informed about the study. The participants expressed their written consent to participate by sending an e-mail to the primary investigator. The study was conducted within March 2021 in Munich city.

\section{B. Participants}

Turkish-speaking participants of a cross-sectional study evaluating COVID-19 knowledge, attitudes, and behaviors [6] were invited to take part in an educational Zoom conference. The patients were consequent applicants to Turkish-speaking family physicians in Munich. All 245 participants of the cross-sectional study were offered to register to an online educational event by sending an e-mail to the primary researcher. In total, 57 indicated their interest in the educational activity, and 29 attended the Zoom conference. From the attendants, 23 responded to the crosssectional survey questions a second time using the Google Forms platform (forms.google.com/) and 25 provided their opinions about the intervention. After excluding questionnaires with conflicting or missing data, 20 valid responses were analyzed for the study questionnaire. Additionally, 21 participants submitted evaluations for the Zoom conference.

\section{Variables and Data Collection}

The primary outcomes of the study were changes in the COVID-19 knowledge scores and vaccination intention. Other study variables were related to attitudes and behaviors regarding COVID-19.

The study questionnaire was developed by the researchers after a literature review and guideline suggestions related to COVID-19. The knowledge domain contained 25 true/false items. Knowledge scores were calculated by summing up the correct answers giving a minimum possible score of 0 and a maximum score of 25 . The attitude and behavior domains included each 7 items arranged in a 5-point Likert scale (1=disagree/never, thru 5=agree/very frequent) (Appendix). Attitude and behavior scores were calculated by adding the scores of each item and dividing by the total number of items, revealing minimum and maximum possible scores of 1 and 5 . Higher scores indicated more sensitive attitudes and behaviors. A descriptive presentation of the responses to the three domains is provided as appendix to this manuscript.
The questionnaire was made available in German and Turkish. There was a 2-3-weeks time-gap between the first attempts of taking the survey questionnaire and the second application of the online version. At the end of the Zoom conference, the participants were asked to evaluate the educational activity using a 13-item educational session evaluation form on a 5-point Likert scale (1=very bad, thru $5=$ very good) [8]. This form too was made available online using Google Forms.

\section{The Intervention}

The educational intervention was composed of a 40-minute interactive Zoom conference. During the Zoom event, the content of a patient education leaflet about COVID-19 was presented to the participants using audio-visual methods (15 minutes), followed by a discussion, questions, and answers (25 minutes). The presentation comprised facts and figures about the COVID-19 pandemic as well as its ways of spread, treatment options, preventive precautions, and vaccination. The seminar was prepared in accordance with patient leaflet of the German College of General Practitioners and Family Physicians (available at https://www.degam.de/patienteninformationen.html) and translated into Turkish by the principal investigator. The presentation and discussion were conducted through video conferencing with Zoom (www.zoom.com) in Turkish. Two Turkish-speaking authors (ZA and RK) attended the meeting to answer the questions of the participants. Additionally, one family medicine professor from Turkey attended the discussion section.

\section{E. Statistical Methods}

The data were entered into the IBM SPSS v25.0 Statistics (IBM Corp, Armonk, NY) software. The data distribution was described within and across the study groups by frequencies, percentages, means, and standard deviations (SD), as appropriate. Corresponding hypothesis testing of univariable group differences was performed by the McNemar's test, and the paired samples t-test. Hypothesis testing was performed at exploratory two-sided $5 \%$ significance levels.

\section{RESUlTS}

Participants of the repeated assessment aged in average $42.0 \pm 11.6$ years (min. 21, max. 63) and had relatively high educational levels. Most were born in Turkey (Table I).

TABLE I: PARTICIPANT CHARACTERISTICS

\begin{tabular}{|c|c|c|c|}
\hline & & Mean (min-max) & $\mathrm{SD}$ \\
\hline Age & & $42.0(21-63)$ & 11.6 \\
\hline \multirow{2}{*}{ Total years of schooling } & & $15.0(5-18)$ & 3.1 \\
\hline & & $\mathrm{n}$ & $\%$ \\
\hline \multirow[t]{2}{*}{ Sex } & Female & 9 & 45 \\
\hline & Male & 11 & 55 \\
\hline Had been infected with & Yes & 5 & 25 \\
\hline COVID-19 & No & 15 & 75 \\
\hline \multirow{2}{*}{ Place of birth } & Turkey & 15 & 75 \\
\hline & Germany & 5 & 25 \\
\hline
\end{tabular}

SD: Standard deviation.

The knowledge and behavior scores of the participants did not change after the intervention. However, there was a significant increase in the attitude scores from mean 3.8 to 4.2 
(Table II).

TABLE II: COMPARISON OF THE KNOWLEDGE, ATTITUDE, AND BEHAVIOR SCORES BEFORE AND AFTER THE INTERVENTION

\begin{tabular}{ccccccc}
\hline \hline & \multicolumn{3}{c}{ Before } & \multicolumn{2}{c}{ After } & \multirow{2}{*}{ * } \\
\cline { 2 - 5 } & Mean & SD & Mean & SD & & \\
\hline Knowledge score & 22.8 & 1.5 & 23.1 & 1.5 & 1.241 & 0.230 \\
Attitude score & 3.9 & 0.5 & 4.2 & 0.5 & 2.919 & $\mathbf{0 . 0 0 9}$ \\
Behavior score & 4.1 & 0.4 & 4.2 & 0.3 & 1.252 & 0.226 \\
\hline \hline
\end{tabular}

SD: Standard deviation, *Paired samples t-test.

TABLE III: COMPARISON OF THE INTENTIONS TO BE VACCINATED BEFORE AND AFTER THE INTERVENTION

\begin{tabular}{ccccc}
\hline \hline \multirow{2}{*}{ Will you get vaccinated against } & \multicolumn{2}{c}{ After } & \multirow{2}{*}{ Total } \\
\cline { 2 - 4 } COVID-19? & No & Yes & \\
\hline \multirow{2}{*}{ Before } & No & $5(71.4 \%)$ & $2(28.6 \%)$ & $7(35.0 \%)$ \\
& Yes & $1(7.7 \%)$ & $12(92.3 \%)$ & $13(75.0 \%)$ \\
\hline \hline & Total & $6(100 \%)$ & $14(100 \%)$ & $20(100 \%)$ \\
\hline \hline
\end{tabular}

McNemar $\mathrm{p}=1.000$
In the session evaluation, the Zoom session received generally high scores from the participants (mean 4.7, standard deviation 0.2). Also, the free-text evaluations were positive and encouraging (Table IV).

\section{DISCUSSION}

\section{A. Key Findings}

In this study, one session of interactive online Zoom intervention in the form of a short presentation followed by a discussion was feasible and evaluated positively by the participants. There was no sufficient time gap to observe modifications in the behaviors. Also, the already high knowledge scores showed a small non-significant increase. However, the attitude scores significantly improved from a mean of 3.87 to 4.20 .

TABLE IV: RESPONSES OF THE PARTICIPANTS TO THE OPEN-ENDED EVALUATION QUESTIONS AFTER THE ZOOM SESSION

\begin{tabular}{|c|c|c|}
\hline What I liked best from this session & What I learned from this session & $\begin{array}{l}\text { I suggest the following changes in this } \\
\text { session next time }\end{array}$ \\
\hline Being interactive & $\begin{array}{l}\text { I learned more concrete experiences about } \\
\text { the corona. }\end{array}$ & $\begin{array}{l}\text { More information about content and } \\
\text { objectives could have been given in } \\
\text { advance. }\end{array}$ \\
\hline $\begin{array}{l}\text { Supported with a presentation. Giving the participants } \\
\text { the opportunity to speak. }\end{array}$ & $\begin{array}{l}\text { It does not matter, whichever route the virus } \\
\text { emerged. The important thing is how do I } \\
\text { protect and get rid of this problem. }\end{array}$ & You answered all questions sincerely. \\
\hline $\begin{array}{l}\text { I have seen the application of the idea that we can use } \\
\text { online meetings in social awareness projects. }\end{array}$ & Protection rates of vaccines. & $\begin{array}{l}\text { Informing prospective participants about } \\
\text { using the Zoom program in advance may } \\
\text { increase the attendance rate. }\end{array}$ \\
\hline $\begin{array}{l}\text { Having doctors among the participants. The presenter } \\
\text { was enthusiastic and excited. The session was short and } \\
\text { to the point. }\end{array}$ & $\begin{array}{l}\text { I learned the explanation of } \\
\text { "Reproduktionszahl". }\end{array}$ & $\begin{array}{l}\text { At the beginning, it may be more beneficial } \\
\text { for the participants to be muted. Moderator } \\
\text { should be someone else who takes the } \\
\text { questions in order and allows to speak in an } \\
\text { order. }\end{array}$ \\
\hline $\begin{array}{l}\text { There was a sincere atmosphere in explanatory } \\
\text { discussions. }\end{array}$ & $\begin{array}{l}\text { The importance and necessity of getting } \\
\text { vaccinated. }\end{array}$ & Thank you. \\
\hline The explanations were persuasive. & $\begin{array}{l}\text { I learned better how Covid } 19 \text { affects our } \\
\text { lives. }\end{array}$ & $\begin{array}{l}\text { You can inform us about such presentations } \\
\text { from time to time. }\end{array}$ \\
\hline It was informative and revealing. & $\begin{array}{l}\text { Covid is a disease that should be taken } \\
\text { seriously. }\end{array}$ & $\begin{array}{l}\text { It is beneficial to have different speakers in } \\
\text { a session. }\end{array}$ \\
\hline Sharing information and having a brief content. & Blood groups play no role in the disease. & $\begin{array}{l}\text { Pay attention to the private data protection } \\
\text { law. }\end{array}$ \\
\hline $\begin{array}{l}\text { I felt in a relaxed family atmosphere. It wasn't boring. I } \\
\text { found it fun and informative. I wish it would be } \\
\text { repeated }\end{array}$ & $\begin{array}{l}\text { I definitely didn't want to be vaccinated. } \\
\text { Now I'm starting to think that maybe I could } \\
\text { be. }\end{array}$ & $\begin{array}{l}\text { I liked it in every aspect. I don't have any } \\
\text { additional suggestions for now. Thanks. }\end{array}$ \\
\hline Questions of the participants were answered sincerely. & $\begin{array}{l}\text { It helped us to resolve our hesitations about } \\
\text { the Covid_19 vaccine }\end{array}$ & $\begin{array}{l}\text { The more people can be reached, the more } \\
\text { people will benefit from this valuable } \\
\text { information. }\end{array}$ \\
\hline Questions found answers. & It was clear. & $\begin{array}{l}\text { I wish the continuation of your success. } \\
\text { Hope we can benefit more. }\end{array}$ \\
\hline I wish this field wouldn't be mandatory :) & I wish this field wouldn't be mandatory :) & $\begin{array}{l}\text { The session can be repeated with a different } \\
\text { content. }\end{array}$ \\
\hline The presentation. & Covid -19 & Slides and references can be shared. \\
\hline That the subject was not dispersed, but informed guests. & $\begin{array}{l}\text { The coronavirus will remain in our lives for } \\
\text { a while. }\end{array}$ & No suggestion. \\
\hline $\begin{array}{l}\text { Many people got their say, I could hear different } \\
\text { opinions. }\end{array}$ & $\begin{array}{l}\text { The corona virus should not be } \\
\text { underestimated. }\end{array}$ & $\begin{array}{l}\text { In order for many people to be informed, } \\
\text { there must be more participants and } \\
\text { speakers. }\end{array}$ \\
\hline $\begin{array}{l}\text { It was a very friendly atmosphere. It was a presentation } \\
\text { that everyone could understand. }\end{array}$ & $\begin{array}{l}\text { I guess I found a little bit more courage to } \\
\text { get vaccinated. }\end{array}$ & $\begin{array}{l}\text { Everything was fine. I would like to meet } \\
\text { more frequently on new programs that cater } \\
\text { to much larger groups, including other } \\
\text { health issues. }\end{array}$ \\
\hline $\begin{array}{l}\text { The session was in the form of questions and answers } \\
\text { and curious questions were answered. }\end{array}$ & The corona vaccine is safe. & $\begin{array}{l}\text { Participants' time use can be reduced by } \\
\text { preventing unnecessary speeches other than } \\
\text { asking questions. }\end{array}$ \\
\hline $\begin{array}{l}\text { Everyone was allowed to speak, and every question was } \\
\text { tried to be answered. }\end{array}$ & - & - \\
\hline Satisfactory answers were given to the participants. & $\begin{array}{l}\text { I learned that the vaccine developed for } \\
\text { Covid-19 is protective. }\end{array}$ & $\begin{array}{l}\text { In order to be useful for a wider audience, } \\
\text { the program needs to be announced to more } \\
\text { people. }\end{array}$ \\
\hline The presentation was well prepared. & $\begin{array}{l}\text { We must prepare ourselves to live with this } \\
\text { virus for a longer time. }\end{array}$ & $\begin{array}{l}\text { Participants should be allowed to join } \\
\text { without using a code. The code is not } \\
\text { practical. }\end{array}$ \\
\hline The answers to the questions were sufficient. & The importance of vaccination. & No idea. \\
\hline
\end{tabular}




\section{B. Limitations}

This study was conducted with a relatively small sample size. Besides, the participants had a mean educational attainment of 15 years, corresponding to some higher education. Therefore, caution is warranted when generalizing the findings. Furthermore, this is a before-after comparison without a control group.

\section{Interpretation}

Our previous findings indicating that the number of patients not intending to get vaccinated is higher in those with a migration background [6] makes this educational intervention more important. The number of participants in the intervention ( 29 from 245 invited) shows a low interest in the proposed educational activity. Ideas should be developed to encourage involvement. Methods such as providing economic or other incentives and accessing the persons via influential keypersons from their own community could increase the participation rate.

Of the people with roots in Turkey, $22.5 \%$ of men and $19.9 \%$ of women had some higher education, which is lower compared to the native Germans [9]. Our subjects had comparatively higher educational levels. We believe that this difference is due to volunteer bias [10]. Therefore, is should be taken into consideration that an intervention study in the general population with Turkish roots might have challenges related to the educational level of the participants.

The proportion of the public already infected with COVID19 is steadily increasing. As of January 15, 2021, almost $15 \%$ of adults in metropolitan France had this ailment [11]. Therefore, 25\% infection rate in our study as of March 2021 seems to be a comparative figure.

Interactive educational interventions have been shown to have a positive effect on perceptions and attitudes towards immunization [12]. The educational intervention implemented in this study was a short online presentation followed by an interactive discussion. However, it is well known that any intervention will have some degree of benefits [13]. Therefore, the effectiveness of the intervention relative to a control group and its long-term outcomes need to be shown in other study designs. Furthermore, the intervention could achieve a change in the attitudes but not in knowledge or behaviors. Since the second data collection was done right after the intervention, there was no time gap for any behavioral change. On the other side, the knowledge scores were already high at the first measurement. Thus, there was not much area to improve with the seminar. However, the small increase in the knowledge scores could become significant after another seminar attempt or increasing the duration of the intervention.

Most importantly, the 40-minutes interactive seminar has achieved significant improvements in the attitudes of the audiences. It is not easy to modify the attitudes of adults [14]. Not many people easily accept or adapt to modification [15]. People will often behave in ways that their community believe is right. Therefore, a certain level of trust must be achieved between the learners as well as the learners and the facilitator in order to accomplish change [16]. Besides, adults must be given enough opportunity to think, reflect, conceptualize, and discuss [17]. From this perspective, faceto-face educational activities can be more efficient in helping a person transforming his/her mind. Thus, we suggest performing presence courses whenever possible.

Effectively motivating patients to change their health behavior is crucial for family physicians. Approximately $40 \%$ of deaths are attributed to modifiable health behaviors [18]. Changing attitudes is the most essential step in achieving behavioral change. Interventions that modify attitudes and norms are useful in endorsing health behavior change [19]. Several methods have been suggested to succeed in this difficult task. Repeated boosters of the educational activity, rewarding good behaviors, and aiming specific small steps each time are some common characteristics of the different methods [20].

Although this study showed the benefit of the online seminar discussion on modifying the attitudes, this was not reflected on the intention to get vaccinated. While two participants changed their opinion for vaccination, one person decided on the opposite. Still, we may expect that the change will become significant when working with larger number of subjects. In light of these information, we suggest multiple educational sessions with the same participants to increase the amount of transformation.

Finally, the Zoom session was highly welcomed and positively rated by the participants (mean 4.7 points out of possible 5). The enormous growth in the virtual conferencing market has probably changed the perceptions of people, making online events as the default [21]. Although face-toface sessions could possibly show a better performance in modifying attitudes, recent trends due to COVID-19 have probably increased the familiarity and acceptance of people for distant education. The individual remarks indicated that having a friendly environment, where participants were allowed to express their opinions were valued.

\section{CONCLUSION}

Although the educational intervention caused a significant change in the attitude of participants, the single educational session was not sufficient to achieve a transformation in the behaviors or intention to be vaccinated. We suggest conducting educational interventions in larger scales involving key persons from the Turkish-speaking community as peer trainers in order to change the negative attitudes towards vaccination.

\section{ACKNOWLEDGMENT}

We thank Prof. Memet Isik for attending and contributing to the Zoom discussion.

\section{APPENDIX}

Distributions of the correct knowledge answers and mean \pm SD values for the attitude and behavior domains compared between the first study [6] and the current repeated measurement. 


\begin{tabular}{|c|c|c|}
\hline Subscale 1: COVID-19 Knowledge & $\begin{array}{l}\text { Before } \\
{[\mathrm{n}(\%)]}\end{array}$ & $\begin{array}{c}\text { After } \\
{[\mathrm{n}(\%)]}\end{array}$ \\
\hline 1. The cause of the Corona-infection is a virus & $353(87.4)$ & $19(95.0)$ \\
\hline 2. How COVID-19 spreads is not known & $287(69.5)$ & $16(80.0)$ \\
\hline $\begin{array}{l}\text { 3. COVID-19 can spread through the air in enclosed } \\
\text { spaces }\end{array}$ & $388(93.3)$ & $17(85.0)$ \\
\hline $\begin{array}{l}\text { 4. COVID-19 can spread through close contact (e.g. } \\
\text { hugging) }\end{array}$ & $394(93.8)$ & $19(95.0)$ \\
\hline 5. COVID-19 can spread through sexual contact & $242(59.9)$ & $9(45.0)$ \\
\hline 6. COVID-19 is often transmitted through food & $333(80.2)$ & $20(100)$ \\
\hline $\begin{array}{l}\text { Which measures can reduce the risk of transmitting } \\
\text { COVID-19? }\end{array}$ & $408(96.5)$ & $20(100)$ \\
\hline $\begin{array}{l}\text { 7. Washing hands after touching potentially infected } \\
\text { surfaces }\end{array}$ & $412(97.4)$ & $20(100)$ \\
\hline 8. Wearing a face mask when entering crowds & $368(90.2)$ & $20(100)$ \\
\hline 9. Taking antibiotics & $335(80.5)$ & $17(85.0)$ \\
\hline 10. Drinking vinegar & $363(87.5)$ & $19(95.0)$ \\
\hline 11. Drinking carrot juice & $405(96)$ & $20(100)$ \\
\hline 12. Keeping a distance of 1.5 meters from people & $400(95.7)$ & $20(100)$ \\
\hline 13. Lubricate butter in the nostrils & $311(75.1)$ & $17(85.0)$ \\
\hline 14. Eating garlic & $222(54.8)$ & $12(60.0)$ \\
\hline 15. The use of the Corona app & $401(94.8)$ & $20(100)$ \\
\hline $\begin{array}{l}\text { 16. Frequent ventilation when in the same room } \\
\text { with others }\end{array}$ & $374(88.6)$ & $20(100)$ \\
\hline 17. Avoiding closed rooms with strangers & $397(94.3)$ & $20(100)$ \\
\hline 18. Avoiding & $382(91.0)$ & $18(90.0)$ \\
\hline 19. Drinking holy water & $394(94.3)$ & $18(90)$ \\
\hline $\begin{array}{l}\text { Which of the following symptoms are common in } \\
\text { COVID-19? }\end{array}$ & $407(96.9)$ & $20(100)$ \\
\hline 20. Cough & $363(89.4)$ & $20(100)$ \\
\hline 21. Fever & $395(96.8)$ & $20(100)$ \\
\hline 22. Dysuria & $387(95.3)$ & $20(100)$ \\
\hline 23. Increased appetite & $391(93.8)$ & $20(100)$ \\
\hline 24. Weight gain & $287(69.5)$ & $20(100)$ \\
\hline 25. Loss of taste and smell & $388(93.3)$ & $20(100)$ \\
\hline Subscale 2: COVID-19 Attitude & & \\
\hline $\begin{array}{l}\text { 5-Agree, 4-Partially agree, 3-Not sure, 2-Partially } \\
\text { disagree, 1-Disagree }\end{array}$ & Mean \pm SD & Mean \pm SD \\
\hline 1. COVID-19 is dangerous & $4.47 \pm 1.04$ & $5.90 \pm 0.30$ \\
\hline 2. In reality, COVID-19 does not exist & $1.63 \pm 1.24$ & $1.10 \pm 0.44$ \\
\hline 3. The danger of COVID-19 is exaggerated & $2.42 \pm 1.52$ & $2.10 \pm 1.29$ \\
\hline 4. I am afraid of dying if I should get COVID-19 & $2.50 \pm 1.45$ & $3.05 \pm 1.50$ \\
\hline 5. Believers are protected from COVID-19 & $1.47 \pm 1.12$ & $1.0 \pm 0.0$ \\
\hline $\begin{array}{l}\text { 6. COVID-19 was created purposely to control the } \\
\text { world }\end{array}$ & $2.47 \pm 1.50$ & $2.05 \pm 1.23$ \\
\hline $\begin{array}{l}\text { 7. Vaccination against COVID-19 is safe } \\
\text { Subscale } 3 \cdot \text { COVID-19 Behavior }\end{array}$ & $3.19 \pm 1.29$ & $3.70 \pm 0.80$ \\
\hline $\begin{array}{l}\text { 1-Never, 2-Very rare, 3-Off and on, 4-Frequent, 5- } \\
\text { Very frequent }\end{array}$ & Mean \pm SD & Mean \pm SD \\
\hline 1. How often do you wash your hands? & $4.38 \pm 0.64$ & $4.55 \pm 0.51$ \\
\hline $\begin{array}{l}\text { 2. How often do you wear a mask when you are } \\
\text { outside? }\end{array}$ & $4.19 \pm 0.90$ & $4.40 \pm 0.75$ \\
\hline $\begin{array}{l}\text { 3. How much attention do you pay to keeping } \\
\text { distance? }\end{array}$ & $4.16 \pm 0.88$ & $4.50 \pm 0.51$ \\
\hline 4. How often do you accept guests? & $2.13 \pm 0.88$ & $2.10 \pm 0.64$ \\
\hline 5. How often do you go visiting others? & $1.82 \pm 0.91$ & $2.10 \pm 0.91$ \\
\hline 6. How often do you enter crowded places? & $2.05 \pm 0.91$ & $2.05 \pm 0.60$ \\
\hline 7. How often do you use public transport? & $2.27 \pm 1.23$ & $1.85 \pm 0.74$ \\
\hline
\end{tabular}

\section{REFERENCES}

[1] Statista Research Department. Anzahl der Ausländer in Deutschland nach Herkunftsland von 2018 bis 2020. Stat GmbH 2021. https://de.statista.com/statistik/daten/studie/1221/umfrage/anzahl-der- auslaender-in-deutschland-nach-herkunftsland/ (accessed March 31, 2021).

2] German Federal Foreign Office. Germany and Turkey: Bilateral Relations 2020. https://www.auswaertigesamt.de/en/aussenpolitik/turkey/228290 (accessed January 17, 2021).

3] Costanzo D. Ausländer-Report: Zahlen für Bayern \& München. TZ 2011:27.09. https://www.tz.de/muenchen/stadt/auslaender-report-tz1422167.html (accessed May 15, 2021).

[4] Eskiocak M, Marangoz B. [Status of Immunization Services in Turkey]. Ankara: Turkish Medical Association; 2019.

[5] Bundeszentrale für politische Bildung. Die neue Diasporapolitik der Türkei und Türkeistämmige in Deutschland 2018. https://www.bpb.de/apuz/280578/die-neue-diasporapolitik-dertuerkei-und-tuerkeistaemmige-in-deutschland (accessed April 28, 2021).

[6] Aktürk Z, Linde K, Hapfelmeier A, Kunisch R, Schneider A. COVID19 vaccine hesitancy in people with migratory backgrounds: A crosssectional study among Turkish- and German-speaking citizens in Munich. (Unpublished Work 2021. doi:10.21203/rs.3.rs-493056/v2.

[7] Mueller C., "Integrating Turkish communities: a German dilemma," Popul Res Policy Rev, vol. 25, pp. 419-441, 2006.

[8] Aktürk Z, Acemoğlu H, Cansever Z, Işık M. ATAG Educational Session Evaluation and Feedback Tool. 10th Natl. Turkish Fam. Med. Congr., Fethiye: .18-22 May 2011.

[9] Schührer S. Türkeistämmige Personen in Deutschland: Erkenntnisse aus der Repräsentativuntersuchung" Ausgewählte Migrantengruppen in Deutschland 2015"(RAM). Nürnberg: 2018

[10] Ganguli M, Lytle ME, Reynolds MD, Dodge HH., "Random versus volunteer selection for a community-based study," Journals Gerontol Ser A Biol Sci Med Sci, vol. 53, pp. M39-46, 1998.

[11] Hozé N, Paireau J, Lapidus N, et al. Monitoring the proportion of the population infected by SARS-CoV-2 using age-stratified hospitalisation and serological data: a modelling study. Lancet Public Heal vol. 6, pp. e408-e415, 2021.

[12] Blanchard J, Johnson C, McIntyre M, Crowcroft NS, McLellan A. A pre and post intervention study measuring the effect of interactive education on adolescent perceptions of vaccines, vaccine safety and disease risk. J Public Health (Bangkok) 2020;42:e272-7.

[13] Hutchinson L., "Evaluating and researching the effectiveness of educational interventions," $B M J$, vol. 318, pp. 1267-1269, 1999. doi:10.1136/bmj.318.7193.1267.

14] Preston J, Feinstein L. Adult Education and Attitude Change [Wider Benefits of Learning Research Report No. 11]. In: Albarracín D, Johnson BT, Zanna MP, editors. Handb. attitudes, Lawrence Erlbaum Associates Publishers; 2005, pp. 173-221.

[15] Hmelo-Silver CE., "Problem-based learning: What and how do students learn?" Educ Psychol Rev, vol. 16, pp. 235-266, 2004.

16] Doyle T. Learner-centered teaching: Putting the research on learning into practice. Stylus Publishing, LLC.; 2012.

17] Bouton ME. "Why behavior change is difficult to sustain," Prev Med (Baltim), vol. 68, pp. 29-36, 2014

[18] Mokdad AH, Marks JS, Stroup DF, Gerberding JL., "Actual causes of death in the United States, 2000," JAMA vol. 291, pp. 1238-1245, 2004. doi:10.1001/jama.291.10.1238.

[19] Petty T, Thomas C., "Approaches to a successful adult education program," Coll Stud J, vol. 48, pp. 473-480, 2014.

[20] Hooker S, Punjabi A, Justesen K, Boyle L, Sherman MD., "Encouraging Health Behavior Change: Eight Evidence-Based Strategies," Fam Pract Manag, vol. 25, pp. 31-36, 2018.

[21] Malara N., Nellis S., Zoom Sees 355 Percent Revenue Leap on Rise of Virtual Meetings, Skift, 2020 https://skift.com/2020/08/31/zoom-sees355-percent-revenue-leap-on-rise-of-virtual-meetings/ (accessed April 29, 2021). 